Bethan Loftus: "Police Culture in a Changing World", Clarendon Studies in Criminology, Oxford University Press, 2009. (256 s.)

Loftus bok Police Culture in a Changing World vil med all sannsynlighet gå inn som en klassiker blant studiene av politikulturer. Noe annet vil overraske. Det er en bok som alle som bedriver politiforskning bør kjenne til og en viktig bok for de som arbeider for å forandre politiet.

Loftus studie av politikultur bygger på grundige etnografiske studier av politiets virksomhet i to lokaliteter kalt Northville og Southville. Northville er en relativt stor by med betydelig innslag både av innvandrede folkegrupper og marginaliserte nabolag preget av stor arbeidsløshet. Southville er i motsetning et mer landlig sted hvor selve byen er liten med store omkringliggende landbruksområder. Loftus har fulgt politiet på jobb begge disse steder og det er et klart fortinn ved studien at den ikke kun hviler på data fra politiets arbeid i storbyområder.

Som tittelen på studien indikerer så er hennes hovedfokus politikulturen i dagens samfunn. Hun spør hvordan og om politiet har tilpasset seg de krav som stilles til økt sensitivitet overfor etniske grupper, kvinners rettigheter og toleranse overfor homofile. Sagt på en annen måte hvordan politiet i praksis takler kravet om toleranse overfor mangfold både innen egen etat og i samfunnet forøvrig. Sentrale trekk i de klassiske studiene av politikulturen viser til høy grad av intoleranse overfor svarte og homofile samt en grunnleggende machokultur preget av mannlige idealer. Politimannen var og er fortsatt, viser Loftus, stort sett en stor, sterk, heterofil, hvit mann.

I likhet med flere nordiske studier finner Loftus at mange av de typiske trekkene ved politikulturen som dokumenteres i amerikanske og britiske studier fra 1960 og 70- tallet fortsatt har stor grad av gyldighet. De kulturelle trekkene ser man fortsatt tydelig, men de er noe forandret. Med stort press fra både politisk hold og egen ledelse nedfelt $\mathrm{i}$ en rekke retningslinjer og krav om økt toleranse og service overfor kvinner, etniske minoriteter og homofile kan ikke åpenlys forskjellsbehandling foregå som før. Den tydelige rasismen, homofobien og sexismen finner Loftus også i mindre grad enn tidligere. I stedet lever disse verdiene et liv backstage, når publikum ikke hører eller ser politiet, når de sitter på piketten. Loftus dokumenterer på en god måte den spenningen som oppstår mellom de tidvis ganske tydelige intolerante holdningene og forbudet mot å uttrykke dem åpent, men i stedet fremstå som servicevennlige og åpne overfor publikum. Disse kravene oppleves som ganske krevende å forholde seg til og møter betydelig motstand fra 
politimennene. De oppleves dessuten som pålagt dem av politiets ledelse, noe som ytterlige er med på å forsterke avstanden mellom ledelse og ute-politiet.

Politiets usolidariske opptreden overfor kvinner, homofile og betjenter med minoritetsbakgrunn er ikke lystig lesing. Kvinnene er de som har kommet lengst i integreringen inn i politiyrket. Når man leser hvordan svarte eller homofile politimenn behandles, sjelden direkte, men desto oftere med mer indirekte teknikker og tiltaleformer så kan man undres over hvordan mange av dem holder ut i yrket. For fargede politimenn kan det dessuten være en ekstra belastning at de ofte ikke godtas helt verken i egen etat eller hos sine egne. Uttrykk som "Bounty sjokolade" og "Kokosnøtt" beskriver at de oppfattes som svarte utenpå, men hvite inni. Politiyrket er preget av en sterk kultur og følelse av et vi. For de som ikke slipper inn i gruppen, men som holdes utenfor oppleves det som ekstra belastende. Ulike strategier for å rekruttere fra minoritetsbakgrunn kan lett slå ut galt ved at de skaper ideer om at de har fătt jobben lettere og at de raskere kan stige i gradene på grunn av hudfarge, ikke fordi de er dyktige.

En gruppe som har blitt glemt og utelatt fra mangfoldsidealene er de unge arbeidsledige hvite guttene. Loftus viser at fattige marginaliserte hvite fortsatt relativt åpenlyst behandles på en nedverdigende måte. Skjellsordene som benyttes overfor denne gruppen er flere og vanligvis sterkt nedsettende. Denne gruppen, av policeproperty, er ikke ubetydelig i dagens Storbritannia. Loftus ser ut å glemme en annen gruppe, de narkomane. Det er flere eksempler i boka på tøff behandling av dem, uten at det tas opp som et særskilt problem. Mye tyder på at hun behandler dem som en del av de fattige marginaliserte hvite, men her kunne Loftus vært langt tydeligere enn hva hun er. Personer identifisert som narkomane, eller som på et eller annet vis knyttes til narkotika er nærmest fritt vilt. Et eksempel hun viser til er en gjeng unge hvite gutter som utsettes for betydelig oppmerksomhet og utspørring fra politihold. Ingen av dem var registret for noen ting i politiets register. Hvorfor ble de så grundig sjekket ut? Loftus påpeker at de tilhører gruppen av fattige hvite, men politiet selv opplyser at en av guttene har en bror som selger av narkotika og at han og vennene derfor burde kontrolleres.

En annen gruppe hvor politiet har langt igjen er kvinner som ikke fremstår som ideelle offer, eksempelvis prostituerte eller berusede voldtektsoffer. Disse behandles i alle fall på overflaten skikkelig, men Loftus observasjoner viser at deres anmeldelser sjelden følges opp og at de omtales på til dels svært nedsettende måter i politibilen eller på stasjonen.

En styrke i Loftus bok er kvaliteten på hennes etnografiske data. Måten intervjuer benyttes, særlig gruppeintervjuer, er svært god. Hun bruker også feltnotater på en våken og sensitiv måte som viser en forsker av rang. Bruken av dataene gir oss en nærhet til feltet som er av stor betydning. Det gir også studiens funn stor 
troverdighet. Mange av bokas funn kan virke relativt støtende og som hard kost sett fra nordisk hold, derfor er det ekstra viktig at de presenteres på en måte som understøttes av gode observasjoner og data.

Avslutningsvis kan en spørre om denne studien har noen relevans for nordiske forhold. Det mener jeg så avgjort, selv om man kan se flere forskjeller mellom Storbritannia og Norden. En betydelig forskjell ligger i avstanden mellom politi og publikum. Loftus politi opplever å nærmest være i krig med resten av verden. De blir spyttet på og hånet, også av "vanlig folk". Dette gjør at det utvikles en ekstra sterk korpsånd. Skillet mellom politi og befolkning ser en tydelig i en dem / oss innstilling. Politiet oppfatter selv at de nærmest er i krig med samfunnet og uten dem hadde det vært det rene kaos. Dette skillet mellom politi og publikum er nok et nærmest universelt trekk ved politiyrket, men styrken på det varierer. Hvor Finstads, Holmbergs og Granérs forskning viser en grunnleggende ambivalens og tidvis mistenksomhet overfor publikum, er Loftus politifolk mye klarere i sin avstand. Dette henger nok også sammen med den ulike status som politiyrket har i Norden og Storbritannia. Det er klart at dette også påvirker styrken på og utformingen av politikulturen.

Det er også forskjeller i grad av reformering av politiet. Det ble reist meget sterk og flengende kritikk av politiet i både Scarman og Mcpherson rapportene. Kritikk som ble fulgt opp med en rekke forandringer og forsøk på omstillinger innen politiet. Disse forandringsforsøkene har blitt fulgt opp fra både politisk ledelse $o g$ fra politiledelsen og har medført en rekke konkrete forandringer i politiets hverdag. Man har også i Norden fulgt opp med forsøk på å skape et mer mangfoldsbevisst og tolerant politi. Reformene har ikke vært like gjennomgripende her, kanskje fordi man ikke har hatt de samme åpenlyse politiskandaler og det samme mediapresset. Uansett er det verdt å merke seg at grunntonen i Loftus bok er ganske klar når det gjelder effekten av reformene. De hjelper noe, også på kort sikt, men den grunnleggende politikulturen som bygger på forskjellsbehandling er ikke borte, den har tatt andre former og rettes til dels mot andre grupper hvor det oppleves som greit. Det vil skje forandringer og de vil ta tid. Fortsatt er politimannen en stor hvit mann - og de kulturelle verdiene gjenspeiler dette. Loftus viser at det er et visst rom for ulike syn innad i politiet, yngre politibetjenter virker ofte mer tolerante og opplyste. Det er likevel klare strukturelle trekk ved politiyrket, jobben de er satt til å gjøre og forventningene om at de skal rydde opp, ta seg av alskens sosiale problemer som er med på fortsatt å prege kulturen, ofte i langt sterkere grad enn offisielle pålegg og rekrutteringsstrategier som vektlegger mangold.

\section{Paul Larsson}


Jesper Ryberg (red.): Løsladt - og hvad så? København: Jurist- og Økonomforbundets Forlag, 2009.

"Løsladt - og hvad så" er på 212 sider og ble utgitt i mars 2009 og omhandler den praksis og de rettslige rammer som er med på å forberede løslatelsen av en innsatt i fengsel.

Boken innholder interessante beskrivelser av utvikling innen straffeutforming og kriminalomsorg. Et overordnet perspektiv er at integrering av tidligere innsatte i samfunnet, og spesielt i arbeidslivet, er sentralt for å forebygge ny kriminalitet. Det kommer også klart fram i boken at utdanning i tilknytning til soning, eller like etter, er kriminalitetsforebyggende. Dette er en bok som bør skape debatt. Det pekes på en rekke trekk ved eksisterende tiltakssystem og regelverk som kan bidra til å hindre integrering av tidligere innsatte i samfunnet.

Det er en god sammenheng mellom de temaene som presenteres i de ulike kapitlene, men det enkelte kapittel kan også godt stå på egne ben. En noe bedre samordning og henvisninger kapitlene imellom ville ha forbedret det samlede inntrykk. Interessant kunnskap er det for eksempel når en ser en konklusjon om de tidligere innsattes relativt høye avhengighet av offentlige ytelser i kapittel 9, i sammenheng med at så mange som 20 pst av alle dansker over 18 år hadde innenfor en periode på 13 år en plettet straffeattest som kan gi dem problemer på arbeidsmarkedet, jf kap. 7. Dette illustrer at levekårsproblemer og avhengighet av offentlig velferdssystem som følge av kriminalitet og straffeforfølgelse sannsynligvis ikke bare gjelder for en liten gruppe.

Det empiriske grunnlaget for påstander og diskusjoner i de ulike kapitlene varierer sterkt. Det gjør seg derfor godt med et avslutningskapittel som beskriver ulike grupper av innsattes inntekter og inntektskilder, arbeid og utdanning før og etter soning. Det ville også vært interessant med opplysninger om de innsattes levekår etter soning i dag sammenlignet med tidligere. Spesielt i lys av påstander $i$ de andre kapitlene - om mindre bruk av prøveløslatelse, mer bruk av skatteattester over tid - antas å ha påvirket de tidligere innsattes integrering og arbeidsmarkedsdeltakelse i negativ retning.

Bokens innledningskapittel er skrevet Hans Jørgen Engbo, cand jur og fengselsinspektør i Anstalten ved Herstedvester. Han skriver blant annet om de formelle krav til handlingsplaner for løslatte samt ulike prosjekter som har vært igangsatt for å forbedre handlingsplanarbeidet. Et interessant tiltak er utviklingen av konkrete målsettinger i tilknytning til løslatelsen, for eksempel at det i kontrakt med kommunene stilles krav om at minst 50 pst av alle løslatte som har sonet minst fire mnd fengsel ved løslatelse, skal ha en bolig av en viss kvalitet og at minst 40 pst skal ha arbeid av en viss kvalitet. I et eget avsnitt om reformtanker er et nøkkelpunkt at kommunene i større grad bør pålegges ansvar for løslatte - "det er noget helt galt 
med den kommunale ansvarsfølelsen". At denne påstanden kan være litt avhengig av øynene som ser, illustreres ved at det i kap 3 henvises til en undersøkelse hvor etatene gjensidig gjør hverandre ansvarlig for manglende samarbeide (s. 74).

Kapittel 2 om "Førtidig løslatelse. Retligt grunnlag og anvendelse" er av Vagn Greve. I kapittelet gis en grundig historisk gjennomgang av endring i reglene av benådning og prøveløslatelse. Forfatteren drøfter spesielt muligheten for å nekte prøveløslatelse etter $2 / 3$ soning av straffen ut fra tilrådelighetskriteriet, og påpeker at det her, gjennom en administrativ beslutning, kan skje en 50 pst forlengelse av straffen i forhold til hva domstolen må antas å ha forventet. Han påviser at andelen avslag i søknad på prøveløslatelse har steget jevnt siden 1986. Han stiller blant annet spørsmål er om man overhodet med den nødvendige presisjon kan skille ut en gruppe som har en særlig risiko for ny kriminalitet. Han påviser at innberetninger av vilkårsovertredelser skjer på veldig uensartet vis og har en viktig påminnelse om at de resosialiserende tiltak som skjer på frivillig basis er mye mer effektive enn påtvungne foranstaltninger. I kapittelet forfølger han sine opprinnelige avgrensninger og diskuterer sine hovedproblemstillingene på en god måte ved både å trekke inn statistikk og verdibaserte vurderinger.

Kapittel 3 omhandler prosjektet "God løsladelse", og er skrevet av Nell Rasmussen og Hanne Ramsbøl. Formålet med prosjektet er forebygging av kriminalitet og å sikre at den løslatte får oppfylt sine rettigheter. Prosjektet skulle munne ut i en rekke forslag til tiltak om god løslatelse. En viktig del av prosjektet var komme fram til en felles forståelse av hva som er god løslatelse på tvers av kommunikasjonsbarrierer mellom ulike etater. En guideline for prosjektet er å strebe etter enkelhet og gjennomsiktig i utvikling av virkemidler, metoder og prosesser.

Diskusjonen i kapittelet beveger seg på tre plan - både et systemteoretisk, metodemessig og et mer praktisk handlingsrettet plan. Det er en stor utfordring å klare å kombinere så forskjellige innfallsvinkler på en god måte. Forfatterne viser gjennom diskusjonen i kapittelet at god løslatelse både handler om å bryte kommunikasjonsmessige og ulike strukturelle hindringer, gode arbeidsplaner og om den enkelte saksbehandlers innsats og vilje til endring. Gjennom kapittelet og avslutningsmessig stiller de spørsmålet om målet om god løslatelse kan nås? Her framkommer at det som har stor betydning er så enkelt (og så vanskelig) som at både forsørgelsesgrunnlaget er på plass og at ingen skal løslates til gaten. Men at heller ikke dette prosjektet har funnet løsningen på de løslattes problemer illustreres i siste setning. "Dermed er det skabt grundlag for et sæt anbefalinger til at skabe en helhedsorienteret og sammenhængende tilgang til samarbejdet mellem systemerne om løsladelse af indsatte."

Kapittel 4 "Pension Skejby - bare et alternativt sted?" Forfatter er Linda Kjoer Minke. Kapittelet handler om soning i et alternativ til fengsel. Pensjonen er den 
eneste av sitt slag i de nordiske land. De fleste plussbeboere (de kriminelt belastede) utgjøres av personer som er utstasjonert av fengselssystemet for fortsatt avsoning. Også ikke-kriminelle opptas som beboere. En undersøkelse av Skejbymodellen ble gjennomført i 2004. Den kvantitative del av undersøkelsen ser på om det er forskjell på residivprosenten mellom personer som har hatt opphold på Pension Skejby, sammenlignet med personer som har hatt opphold på kriminalomsorgens øvrige pensjoner. Residiv er definert som tilbakefall til ny kriminalitet innen en periode på 2 år. Resultatet av denne analysen er at sannsynligheten for residiv (uansett residivets art) er 21 pst lavere for eksperimentgruppen enn for kontrollgruppen. Når det gjelder recidiv til en personfarlig forbrytelse er det ikke signifikant forskjell. Sannsynligheten for utdannelsesmobilitet er nesten dobbelt så stor for eksperimentgruppen som for kontrollgruppen. Mulige årsaker er at samtalene og omgangsformene på institusjonen dreier seg om andre ting enn kriminalitet og de kriminelt belastede får mulighet til å knytte kontakt med ikkekriminelle. Forfatteren stiller avslutningsvis spørsmålet om ikke flere geografiske områder enn Jylland bør ha et slikt tilbud. Dette er en interessant soningsform og en viktig undersøkelse. En ønsker å få vite mer, både om avgrening av aldersgrupper og årsaker til at noen grupper ikke responderer så positivt som andre.

I kapittel 5 skriver Hanne Reumert om saksomkostninger som pålegges og om type omkostninger. Det kan forekomme store variasjoner i omkostninger i sammenlignbare saker. De vises eksempler på at omkostningene i enkelte tilfeller kan komme opp i flere hundre tusen kroner. Dette kan virke i motsatt retning av forebygging av ny kriminalitet. Stor gjeld kan hindre at folk tar utdanning og noen kan se ny kriminalitet som en måte å komme ut av gjeldssituasjonen på. Forfatteren diskuterer noen tiltak, for eksempel at sammenlignbare lovbrudd bør ha de samme omkostninger og om det bør innføres et maksimumsbeløp. Hun stiller et viktig spørsmål om ikke systemet bør utformes slik at saksomkostningene ikke blir en straff som rammer de domfelte med ulik styrke ut i fra deres ulike økonomiske og sosiale situasjon.

Kapitlene 6 og 7 omhandler begge straffeattester eller det plettfrie rulleblad. Lektor i strafferett og kriminologi Anette Storgaard gir i kap. 7 en informativ oversikt over reglene for registrering og sletting fra henholdsvis etterforskningsdelen og avgjørelsesdelen av registeret. Det redegjøres også for hvilke instanser som har rett til innsikt i de ulike registre. Straffeattesten er en attest som utstedes av politiet for private personer etter begjæring. En fengselsstraff vil fremgå av straffeattesten i 5 år etter endelig løslatelse. For unge mellom 15 og 18 år slettes påtaleunnlatelse med vilkår om ungdomskontrakt som bøter allerede etter 1 år. På arbeidsmarkedet ble bruken av straffeattester firedoblet $\mathrm{i}$ en periode på slutten av 90-tallet og har også hatt en vekst etter dette. Det henvises til undersøkelser som 
viser at søkere som har vært i berøring med straffesystemet har vanskeligere med å få jobb enn andre. Forfatterens konklusjon er at systemet med straffeattester er basert på ureflektert vanetenkning. I den avsluttende drøftingen vektlegges forholdet mellom arbeidsgivernes nytte av straffeattester sett opp mot skadevirkningene for de dømte med gode og illustrerende eksempler.

I det etterfølgende kapittel stiller Thomas Søbirk Petersen spørsmålet "I hvilken utstrekning bør en arbeidsgiver ha mulighet for å anmode om opplysninger fra en søkers straffeattest?" Dette angår mange mennesker, nesten 20 pst av alle dansker over 18 år hadde innenfor en periode på 13 år en plettet straffeattest. Han redegjør for ulike former for diskriminering og diskuterer straffeattestenes bidrag til ulikhet og marginalisering av tidligere straffede. Et av forslagene han fremfører er "matching", dvs. at en arbeidsgiver bare kan få opplysninger som er særlig relevante for utførelsen av det aktuelle arbeidet. Han tar til orde for at det i tillegg kan legges inn et krav om at forbrytelsen skal være grov (ubetinget dom på minst 6 mnd fengsel) for å oppgis til arbeidsgiver. I kapittelet er det interessante diskusjoner og forslag til tiltak.

I kapittel 8 om "Straf og rettighedstab" skriver Jesper Ryberg om andre rettsfølger av kriminalitet enn selve straffen. Det grunnleggende brudd med synspunktet om at kriminalitet bør medføre tap av borgerlige rettigheter (som stemmerett og valgbarhet), kom med straffelovsendringene av 1951. Fremdeles er det likevel slik at en person dømt for kriminalitet kan underkastes forskjellige former for diskvalifikasjoner. Forfatteren ser nærmere på hensynet bak disse, blant annet i forhold til utøvelse av bestemte yrker. Hans påstand er at det er et brudd med kravet om proporsjonalitet dersom to personer som blir straffet likt for samme forbrytelse, og den ene i tillegg mister jobben pga rettighetstap (for eksempel ved å bli fratatt førerkort). Konklusjonen er at det er vanskelig med empirisk baserte vurderinger av for eksempel individpreventive begrunnelser for rettighetstap. Rettighetstap fremstår ut fra forfatterens diskusjon som vilkårlige hindringer i veien for de innsattes fortsatte liv.

Det avsluttende kapittel omhandler "Selvforsørgelse og uddannelse efter fængsel" v/ Rasmus Landersø og Torben Trances. Det foretas en sammenligning av situasjonen før og etter soningen og det foretas en sammenligning med ikkekriminelle. I tillegg utføres en egen analyse av de som ikke hadde noen utdanning før de kom i fengsel, men som erverver seg utdanning, enten under soning eller etterpå. Dataene viser - ikke overraskende - at det i høy grad er personer, som både utdanningsmessig, på arbeidsmarkedet og sosialt, klarer seg dårlig, som begår kriminalitet og kommer i fengsel. Samtidig tyder også analysen på at kriminalitet og fengsel gjør situasjonen enda verre. For kriminelle som kun får en kort straff, skjer det kun en mindre forverring av situasjonen etter fengselsoppholdet, men den nye 
dårlige situasjonen biter seg fast og det blir ikke bedre med årene. For kriminelle som får en lang straff, er forskjellen i deres tilknytning til arbeidsmarkedet dramatisk dårligere sammenlignet med tiden før de ble fengslet. For denne gruppen er det tale om en økonomisk nedgang på 26 pst, som uten det sosiale sikkerhetsnett ville vært på 40 pst. Fremgangen for gruppen som tar utdanning, enten i løpet av fengselsoppholdet eller etterpå, er på den annen side så kraftig, at den etter 5 år har innhentet det lønnsmessig tapte. Her er bildet overraskende nok det samme, uansett om personen har sittet over eller under 6 måneder i fengsel.

Mot slutten står det at det er viktig å finne ut $\mathrm{i}$ hvilken grad de soningsformer som i dag benyttes, fremmer eller ødelegger de tidligere innsattes muligheter senere i livet - både de arbeidsmessige og de sosiale. Dette kan samtidig stå som en oppsummering av hele bokens budskap.

\section{Marit Wårum}

Justitiedepartementet Forskningskoordinator

(p.t. i permisjon)

Leif Senholt (red.): Fangselshistorisk Selskab 2008. Årsskrift udgivet af Fængselshistorisk Selskab. (127 s.)

Dansk Fængselhistorisk Selskabs andra årsbok innehåller fyra artiklar. Liksom föregående årsbok - den första - bjuder årets utgåva på en blandning av olika ämnen och infallsvinklar. I årsbokens mest vetenskapligt underbyggda artikel diskuterar forskningsledaren vid Institutet för mänskliga rättigheter, Peter Scharff Smith, användningen av fångarnas egna berättelser som källor till kunskap om fängelselivet. Årsbokens andra längre artikel är fängelseinspektör Hans Jørgen Engbos personliga berättelse om etableringen av det öppna fängelset i Jyderup vilket startade 1988. De två övriga texterna är dels en kortare diskussion kring påföljden arbetshus, av konsulent Leif Senholt, samt ett utdrag ur Vissing Kjeldsens minnesanteckningar om hans arbete med att ansvara för bevakningen av en grupp landssvigere, framför allt så kallade schalburgare, efter andra världskrigets slut. Det är inte möjligt att på detta korta utrymme närmare presentera hela innehållet $\mathrm{i}$ boken varför jag nöjer mig med några ord om de två längre bidragen.

Som Peter Scharff Smith påpekar är fängelselitteratur en genre med speciella förutsättningar och svårigheter när det gäller hur den kan användas. Fängelselitteraturen kan delas in i olika former med avseende på författare och syfte och historien är full av berömda böcker skrivna i eller utifrån erfarenheter från fängelser, mentalsjukhus eller andra inspärrningsinrättningar. En rad kända internationella exempel finns, allt ifrån 500-talsfilosofen Boethius och markis de 
Sade till Oscar Wilde, Brendan Behan, Rosa Luxemburg, Gramsci, Solszjenitsyn, Ho Chi Minh, Caryl Chessman till Nelson Mandela. De "gränserfarenheter" som livet i dessa institutioner gett upphov till har resulterat i såväl romaner, poesi, självbiografiska anteckningar som filosofiska och politiska traktater. Många av författarna bakom fängelselitteraturen har varit eller blivit berömda och verken utmärks i många fall av hög litterär kvalitet. Många har varit, eller i varje fall betraktat sig själva som, politiska fångar. Möjligheten att skriva i fängelserna har emellertid varit relativt få förunnat. Dels har fängelsemyndigheterna oftast försökt förhindra att fångarna i skrift givit uttryck för sina erfarenheter, dels har den stora majoriteten av fångarna inte tillhört den "skrivande klassen". Den stora massan av fångar som levt en kortare eller längre tid av sina liv i fängelser kommer därför endast att finnas kvar som namn och siffror i den oändliga statistik som fängelsmyndigheter producerar eller, i den mån de av olika anledningar befunnits intressanta, omtalats av representanter för dessa myndigheter.

Den mesta fängelselitteraturen är dock ingen "äkta" fängelselitteratur - om man med detta menar att den också skall vara skriven $i$ fångenskap - utan skriven efter frigivningen. Ibland kan dock anteckningar gjorda under fängelsevistelsen ligga till grund för vad som senare publicerats. Scharff Smith har spårat upp ett några berättelser på det danska språket från olika tider nerskrivna av fångar; från Ole Kollerøds från 1840 fram till Preben Wilhjelms från 1950-talet. Kollerøds text är på många sätt den mest intressanta, inte bara för att den är betydligt äldre än de andra exemplen hos Scharff Smith. Sprungen ur tämligen enkla förhållanden och med dagens mått mätt knappt skrivkunnig kan Kollerøds berättelse i betydligt högre grad än de övriga ses som ett vittnesmål "underifrån". Han beskriver en på många sätt eländig fängelsetillvaro med otillräcklig kost och kalla och ohälsosamma utrymmen, korrumperade fångvaktare och våld mellan fångarna men också ett liv inom fängelset som var betydligt "friare" än i de inrättningar som växte fram under 1800-talets senare del. Kontrasten mellan den relativt oreglerade tillvaro i det tidiga 1800-tals tukthus som Kollerød beskriver och vad som framkommer i två fångberättelser från åren 1918-19 är därför mycket stor. I centrum för det fängelse som mötte Niels Johnsen och Frejlif Olsen - båda dömda för att de skrivit olika typer av förgripliga artiklar - stod den strikta regimen och den stränga isoleringen i ensamhet. Även i Preben Wilhjelms beskrivning av sin fängelsetid vid mitten av 1950-talet kvarstod mycket av denna strikta ordning. Det mest intressanta med dessa olika fångberättelser är dock kanske inte beskrivningarna av de materiella förhållandena utan att fångarna genom sina berättelser faktiskt framstår som individer och moraliska subjekt som reflekterar över sin situation, över rätt och fel, över samhället och medfångarna. Samtidigt kan man inte, även under en tämligen kort tids vistelse i fängelset - undgå att hos dem alla se effekter av isoleringen i form av nedstämdhet och självupptagenhet. 
Skillnaderna mellan det tukthus där Kollerød avtjänade sitt straff och fängelserna under 1900-talet och det tidiga 2000-talet är naturligtvis enormt stora men Scharff Smith visar också att fängelset har seglivade strukturella drag vilka till stor del finns kvar ännu idag, detta gäller i såväl Danmark som Sverige och i en stor del av världen i övrigt. Alltjämt är isoleringen - avskiljandet från andra intagna och samhället utanför - och den strikta kontrollen ett centralt inslag i fängelsetillvaron varifrån avsteg alltid möts med misstänksamhet och som därför måste motiveras.

I de öppna fängelser som vuxit fram under 1900-talet har just minskningen av isoleringen stått i centrum. Genombrottet för de öppna fängelserna i Danmark liksom i de övriga nordiska länderna skedde åren efter andra världskriget. I Danmarks fall bidrog inte minst behovet av inrättningar för att ta hand om så kallade landssvigere till etableringen av mer eller mindre öppna fängelser. Som Hans Jørgen Engbo påpekar har, med något undantag, de öppna fängelserna i Danmark inrättats i byggnader och anläggningar som tillkommit för andra ändamål. I Jyderups fall handlar det om en anläggning som ursprungligen byggdes som sprängmedelsfabrik men som genom åren också härbärgerat flera andra verksamheter.

De öppna fängelserna har ofta fungerat som föregångare och "experimentverkstäder" när det gällt reformer och förändringar inom fängelsesystemen. Här har normaliseringsprincipen kunnat förverkligas i betydligt högre utsträckning än vid de slutna anstalterna. Det är inte minst av denna anledning intressant att läsa Engbos bidrag om etableringen av det öppna fängelset i Jyderup på Själland. Läsaren får här en personligt hållen berättelse om bakgrunden till dess tillkomst och om den första tidens praktiska och organisatoriska vedermödor. Engbo uppehåller sig bland annat vid organiseringen av personalen i "enhetsfunktionärer" enligt de riktlinjer som dragits upp av det så kallade AUF-betänkandet (Arbete, Undervisning, Fritid), en delvis omdiskuterad förändring men något som med vissa modifikationer kommit att behållas. En annan aspekt som tas upp är det faktum att öppnandet av fängelser och likartade institutioner ofta möts av oro och misstänksamhet bland boende i närområdet. Engbo beskriver hur kriminalvårdsmyndigheterna genom att tidigt etablera kontakter och bjuda in till olika former av samarbete lyckades övervinna denna oro och skapa förtroendefulla relationer till de närboende. Ett forskningsprojekt utfört efter att fängelset varit i drift några år visade också att de flesta av de närboende hade en positiv inställning till fängelset.

Sammantaget har Fængselhistorisk Selskab åter åstadkommit en liten läsvärd skrift som alla som intresserar sig fängelsehistoria bör kunna ha utbyte av.

Roddy Nilsson

Linnéuniversitetet 
Chambliss William J., Michalowski Raymond \& Kramer Ronald C. State Crime in the Global Age (2010) Boten är på 306 sidor. Willan Publishing.

Antologin "State crime in the global Age" med redaktörerna Chambliss, Michalowski och Kramer, börjar som många andra texter om state crime med ämnets åsidosatta roll inom kriminologin. Staten som en brottslig aktör rönte för första gången stor uppmärksamhet inom kriminologin när Chambliss höll sitt uppmärksammade framförande om "State organised crime" på American Society of Criminology 1989. Många kriminologi forskare har därefter följt i hans fotspår vilket lett till en mängd olika böcker på ämnet (se. bland annat Barak, 1991; Ross, 1995; Friedrichs, 1998; Smeulers \& Haveman, 2008; Cohen, 2001; Green and Ward, 2009; Whyte, 2009; Rothe \& Mullins, 2010).

State-crime forskningen har utmanat den traditionella synen på kriminologin som en lära om individer som brottsliga aktörer; en kriminologi som tidigare främst fokuserat på "nuts, sluts, perverts and drug addicts" (s. xiii). Redaktörerna jämför skiftet i synen på kriminologin med Kuhns "paradigm revolution". Trots genombrottet för en bredare syn på kriminologin och brottsliga aktörer anses ämnesområdet fortfarande ha en åsidosatt position. Å andra sidan har det de senaste åren publicerats en ansenlig mängd forskning inom området. Förra årets American Society (ASC) konferens vittnade också om forskningsfältets utbredning. Utgångspunkten tycks dock fortfarande vara att ämnet kräver en personlig (utöver en professionell) drivkraft. Friedrichs räknar i sitt kapitel i boken upp många av de mer välkända forskarna inom området och hur deras historia ledde dem in på området, däribland Stanley Cohens uppväxt i Sydafrika under apartheid.

Antologin är sprungen ur en workshop som hölls i Spanien 2008, i regi av "International Institute for the Sociology of Law". Boken består av 16 kapitel och är utöver introduktionen uppdelade på tre avsnitt Framing State Crime, The Brutal Realities of State Crime och Responding to State Crime. Boken omfattar en bred skara ämnen som brott begångna i krig, däribland USA:s och Storbritanniens inblandning i den irakiska ekonomin, hur felaktiga domar och därmed frihetsberövningar kan ses som brott samt användningen av överstatliga organ, sanningskommissioner och försoning som strategier för att bemöta staters brottslighet. Syftet är inte, som redaktörerna pekar på i inledningen, att etablera en enda modell för att studera staters brottslighet, utan snarare att väcka frågor kring forskningsområdets expansion i en globaliserad värld. Alla antologins delar kommer av utrymmes skäl dock inte uppmärksammas i denna recension.

Michalowski vänder och vrider i sitt kapitel på hur begreppen stat och brott ska förstås. Med utgångspunkt i den traditionella kriminologins mening av begreppet brott, som kan sträcka sig till en definition som tar utgångspunkt i en handling som strider mot en lag, har olika definitioner av statens brott utvecklats 
och problematiserats. Han återkommer till den inom forskningsfältet ofta diskuterade uppdelning mellan brott och skada (crime vs. harm). Michalowski gör dock en egen uppdelning i tre olika former av definitioner där han väger deras styrkor och svagheter mot varandra. För det första, den juridiska där statens brottslighet ska förstås som något som överträder nationell eller internationell lag, inklusive avtal om mänskliga rättigheter, har som fördel att den baseras på ett erkänt system. Nackdelen däremot är dess begränsning till agerande som staten själv erkänner som nationella eller internationella bestämmelser. En av diskussionerna som återkommer i fler av kapitlen är hur en legalistisk utgångspunkt ska hanteras utifrån antagandet att statliga representanter skapar lagen.

Den andra typen av definition tar sin utgångspunkt i "organizational deviance" och skadligt beteende som stater åsamkar och fördöms för, men som inte nödvändigtvis innebär ett brott mot en definierad lag. Styrkan med detta perspektiv är baserad på etablerade sociologiska teorier om avvikelse och organisationer, samtidigt som det vidgar perspektivet till agerande som ligger utanför det som staten nationellt eller internationellt godtagit som lag. En av svagheterna blir då å andra sidan att det inte är ett lika tydligt ramverk att använda sig av.

Utgångspunkten i den tredje typen av definition är inte hur agerandet regleras eller fördöms utan istället utfallet av det, att det lett till skada. Den breda definitionen innebär större möjlighet att studera staters agerande utifrån en måttstock som inte är lika beroende av statens egna intressen och kontrollsystem. Svagheten ligger dock i den lösa ramen, både i begreppet skada som är knutet till tid och rum och i möjligheten att förankra begreppet i den traditionella kriminologin.

Uppdelningen mynnar sedan ut i en "state-crime wedding cake", där toppen består av "High profile" brott som folkmord, krigsbrott och terrorism. Mellanskiktet av "Semi-tolerated violence" såsom stridande och civila som skadas eller dör i krig, tortyr och omänskliga straff. Bottenskiktet på tårtan består av "Structural violence", som omfattar ageranden eller brist på agerande som leder till skador eller rent av död för individer till följd av exempelvis fattigdom, ojämlikhet eller miljöföroreningar.

Det är inte helt klart om Michalowski med en juridisk definition menar att vi endast kommer kunna studera det längst upp på tårtan. En juridisk utgångspunkt kan visserligen vara begränsande, men utesluter inte att vi även kan studera strukturella problem som inte behöver vara av det allra grövsta slaget. En skiljelinje är rimligtvis, om man med juridisk utgångspunkt inte bara menar att agerande behöver vara reglerat i lag (inklusive konventioner om mänskliga rättigheter) utan också ha inneburit en straffrättslig sanktion. Straffrättsliga sanktioner är i vissa länder (däribland Sverige men inte i andra nordiska länder) inte möjliga att utdela till juridiska personer utan endast till individer. Huruvida andra typer av admini- 
strativa sanktioner som kan åläggas organisationer jämställs med straff varierar i olika länder (Jönsson, 2004).

Michalowski för även en intressant diskussion kring definitionen av staten, som ofta blivit förenklat till regeringen, eller den styrande delen i landet. Förenklingen innebär bland annat att staten förstås som ledarna i landet och fokus sätts inte på staten som en bredare organisation och möjlig brottslig aktör. Istället vill han diskutera ett vidare statsbegrepp där gränserna inte är lika klara och effekterna av staten kan skönjas långt utanför de statliga institutionerna. Michalowski menar att det inom forskningsområdet behövs en fördjupad statsteori och poängterar att det krävs en analys av "vilken stat pratar vi om". Även liknande stater skiljer sig när det kommer till exempelvis deras ekonomiska system, vilket också kommer påverka omfattning och typ av brott staten begår (se också Barak, 1990)

Antologins två tydligaste gemensamma nämnare är krig och USA (till viss del även Storbritanniens inblandning när det kommer till Irak). Utgångspunkten i amerikansk forskning är föga förvånande och inriktning på några av de värsta formerna av statligt agerande som får oerhörda konsekvenser för människors liv blir tydlig redan på bokens omslag som pryds av en stridsvagn framför en glödande jordglob. I ett av de första kapitlen i antologins andra del undersöker Ruggerio under rubriken War as corporate crime relationen mellan krig och brott, både som en del av kriget och som en effekt av det, framförallt med fokus på privata aktörers agerande i Irak. Iadicola sätter i sitt kapitel om The centrality of empire in the study of state crime and violence fingret på en intressant aspekt, nämligen att de länder med makt på den globala världsordningen inte bara kan påverka vad som definieras som brott nationellt utan även internationellt, detta är speciellt träffande för USA menar han. I ytterligare ett kapitel på liknande tema men med en annan vinkel utgår Pearce från Durkheims begrepp om altruism och uppoffring och applicerar dessa på den amerikanska retoriken kring krig. Han hänvisar bland annat till Barak Obamas tal om hur amerikanska samhället byggts på människors uppoffringar från självständighetskriget till Vietnamkriget. Pearce ifrågasätter antagandet om självuppoffring i krig och menar att det snarare handlar om att vissa människor offrar andra människor (vilka oftast har mycket lägre socialt välstånd) för att försvar en politisk och ekonomisk hegemoni. Pearce kapitel anknyter också till David Whytes bidrag The neo-liberal state of exeception in occupied Iraq där han med utgångspunkt i Agambens begrepp om undantagstillståndet, visar hur tillståndet om krig och lagstridigt agerande blivit permanent (jämför Flygheds (2007) begrepp om normalisering av det exceptionella). Den amerikanska invasionen av Irak är också utgångspunkten i Kramers analys (i kapitlet med titeln From Guernica to Hiroshima to Bagdad: the normalization of the terror bombing of civilians) av bombningar av civila och hur även dessa normaliserats sedan andra världskriget som en effekt av krig. 
Ett annat kapitel (Framing innocents: the wrongly convicted as victims of state harm) som väckte mitt intresse, och som också utgår från USA men annan form av problematik än krig, är Westervelt och Cooks. De baserar deras kapitel på en studie där de gjort intervjuer med personer som dömts till dödsstraff och som senare bedömts oskyldiga och frigivits. Med utgångspunkt i Kauzlarich m.fl. (2001) definition om offer för staters skadliga agerande, visar de på hur dessa individer som oftast kommer från mindre privilegierade grupper i samhället på olika sätt har blivit orätt behandlade av offentliga representanter, både före och efter frigivningen. Deras bidrag sätter fokus på det kontinuum av agerande av personer inom rättsväsendet, allt från att genom våld framtvinga erkännanden och fabricera bevis till mer diffust slarv, cynism och stereotypisering som fătt stora effekter.

Några bidrag skiljer ut sig från de två teman, krig och USA. Exempelvis lyfter Dawn L Roth frågan om internationella finansiella institut (IFI:s) kan agera kontrollmekanismer för staters lagbrytande agerande eller om instituten i sig är en brottstödjande och generande faktor. Hon utgår från Kinas biståndspolicies kring ekonomiskt svaga länder i Afrika, och utvecklar hur Kina kan ses som ett alternativt stöd som till skillnad mot IFI:s inte kräver privatiseringar och omvandlingar av det ekonomiska systemet i landet. Hon poängterar dock samtidigt att Kinas egna problem när det kommer till respekten för mänskliga rättigheter knappast kan ignoreras, men att de har potential att utgöra ett alternativ till tidigare lånestrukturer som utgjort en stor risk för att understödja staters brottsliga ageranden.

I ett kapitel i bokens tredje och avslutande del för Stanley ett resonemang kring sannings- och försoningsprocesser och liknande åtgärder för att hantera grova människorättskränkningar, hur dessa processer eskalerat både vad gäller antal och när det gäller internationella aktörers delaktighet. Stanley beskriver processerna som alltmer skilda från lokala aktörer och intressen och mer som en arena för internationella experters (främst från Europa och USA) definitioner av "best practice". I värsta fall så riskerar processerna i sig att leda till exkludering och orättvisa i länder som redan har erfarit kolonialmakters inflytande.

Övergripande kan sägas att boken är en bra introduktion genom de inledande kapitlen till state crime-forskningen, framförallt Michalowskis bidrag. Den innehåller också en del fördjupande kapitel men kanske framförallt en bredd av olika sätt att se på statens lagbrytande beteende. Samtidigt har jag svårt att säga att antologin skiljer sig avsevärt från antologierna som givits ut på samma ämne de senaste åren. Flera av infallsvinklare är i och för sig, mig veterligen, nya men författarna är i stor utsträckning de samma som i andra böcker. En skillnad från äldre antologier, som nämns i denna bok, är att nästan alla författare är kriminologer.

Vid den årliga workshopen kring State crime på ASC 2010, uttrycker en av de mer kända forskarna inom området det som att "vi talar som om vi har en produkt 
som ingen vill köpa”. Så borde det inte upplevas. Även om det för oss i Norden är relativt nya begrepp tycks det i andra delar av världen, kanske främst i USA, vara ett forskningsområde på stark frammarsch. Kanske är det snart dags att lämna underdog-positionen bakom sig och sluta inleda forskning på området med ett försvar för dess existens.

\section{Isabel Schoultz}

Doktorand, Stockholms Universitet

Litteraturförteckning

Barak, G. (1991) Crimes by the capitalist states: An introduction to state criminality. Albany, NY: State University of New York Press.

Cohen, S. (2001) States of denial. Knowing about atrocities and suffering. Cambridge, UK: Polity Press.

Green, P., \& Ward, T. (2004). State crime. Governments, Violence and Corruption. London: Pluto Press.

Jönsson, S. (2004) Straffansvar och modern brottslighet. En idékritisk studie av straffansvar för juridiska personer. Uppsala: Iustus Förlag.

Flyghed, J. (2007) Internationaliseringen av kriminalpolitiken. Nordisk Tidskrift for Kriminalvidenskab. 94.årg, nr.1, s. 74-88.

Friedrichs, O. D. (1998) State crime volume I \& II. Aldershot UK: Ashgate Publishing.

Smeulers, A. \& Roelof, H., (2008) Suprational Criminology: Towards a Criminology of International Crimes. Mortsel: Intersentia.s.3-26.

Ross, J. I. (1995) Controlling state crime. New Brunswick, NJ: Transaction Books.

Rothe, D. L and Mullins, C. W. (2010) State Crime: Current Perspectives. New Brunswick, NJ: Rutgers University Press.

Whyte, D. (2009) Crime of the powerful: A Reader. Berkshire, UK: Open University Press.

Lars-Jonas Nygard: Juryen for fall. Demokrati og rettssikkerhet. Unipub 2010. ISBN 978-82-7477-495-7. 342 pp.

Pensioneret lagdommer Lars-Jonas Nygard har efter sin afgang fra retten gennemført en lang række interviews af lagrettemedlemmer om spørgsmålet, hvordan juryen når frem til sin afgørelse, og bearbejdet dem til en doktordisputats ved det juridiske fakultet ved Universitetet i Oslo. Denne bog er en let udbygning af disputatsen. Hvad forfatteren ikke kunne vide, da han igangsatte arbejdet, men nu gør 
bogen dobbelt velkommen, er, at der just pågår nye seriøse overvejelser i Norge om afskaffelse af juryen eller dens omdannelse med inspiration i den for få år siden lykkeligt gennemførte radikale omlægning af den danske nævningeproces.

Først i bogen gennemgår forfatteren jurysagens historie i Norge med lange og gode citater, herunder den frapperende udtalelse fra Johan Sverdrup om, at lægmænd ikke blot er lige så gode som fagdommere til at bedømme beviser, men bedre (pag. 24), som om juridisk uddannelse og dommererfaring eroderer evnen til at skille sandt fra usandt. Vi får atter den aldrig fuldtud opklarede historie om, hvorfor det ikke trods Andenæs' kolossale prestige lykkedes at afskaffe juryen i forbindelse med straffeprosessloven i 1981 (pag. 30 ff.) eller i 1993; traditionshensynet, jurysagens folkelig-demokratiske nimbus og velargumenterende forsvarere med politisk gennemslagskraft har indtil nu holdt den klassiske jura i live. Under omtalen af den engelske jury havde jeg gerne set en udførligere omtale af fordelene ved at vælge guilty-plea for enedommeren snarere end at tage chancen med juryen (pag. 43), netop i Norge har ændringen af straffelovens $§ 59$ gjort tilståelsesrabatten til et meget vigtigt spørgsmål, både udmålingsmæssigt og processuelt. Fra den koncise omtale af den amerikanske jury så jeg næsten med vantro, at visse distrikter forbyder ikke blot "pausesamtaler" mellem nævningerne inden den formelle votering - i mine største sager, særlig Brixtoftesagen, havde jeg tværtimod stor glæde af de løbende samtaler med domsmændene, som bortset fra min hustru og min hønsehund var de eneste, jeg kunne tale med om sagen - men endog at tage notater under sagen for at sikre, at alle nævninger er lige dårligt forberedte til voteringen (pag. 54, min formulering). Derimod er omtalen af fransk og tysk ret (pag. 58 f.) altfor summarisk. Det interessante ved de to europæiske hovedlandes systemer er netop, at de i det 19. århundrede indførte den engelske jury, men i det 20. århundrede enten opgav den helt (Tyskland 1923) eller modificerede den ved indførelse af fællesvotering mellem læge og juridiske dommere (Frankrig 1941). Forfatteren kunne også have understreget, at lægdommere udtages i Tyskland som i Norden modsat de angelsaksiske lande efter et kvalifikationsprincip snarere end et repræsentativitetsprincip (Asbjørn Strandbakken og jeg har i festskriftet til Vagn Greve redegjort for repræsentativitetsprincippets gradvise og omstridte fremtrængen i Norge og Danmark).

Bogens vægtigste del er de 117 interviews på grundlag af en lang spørgsmålsrække (pag. 80 ff.). Forfatteren har ikke glemt nogen facet af processen frem mod beslutningen. Jeg fremhæver de indtrængende spørgsmål om, hvordan de enkelte jurymedlemmer nåede til en sikker bevisvurdering (pag. 104 ff.). Bl.a. spurgtes de 84, der allerede inden bevisførelsens afslutning besluttede at svare "ja" til skyldspørgsmålet, hvornår de var nået dertil; de afgivne svar fordelte sig på "vet ikke, prøver å holde igjen" (kun 3), "etter tiltaltes forklaring", "etter fornærmedes for- 
klaring", "tidlig under vitneførselen" og "et stykke ind i saken". Se også pag. 289. Omvendt giver svaret pag. 287 en meget fin beskrivelse af en samvittighedsfuld og tænksom nævnings langsomme og omhyggelige udvikling indtil det magiske øjeblik, hvor man kan sige "nu holder det for meg". Det farlige ved en hurtig indre beslutning er, at senere indkommen information uvilkårligt tolkes i lyset af den allerede trufne afgørelse; vi laver automatisk argumenter, som støtter det, vi allerede tror på (pag. 109). Frygten for pausesamtaler er ikke helt skudt ved siden af; ukontrollerede samtaler i mindre grupper kan i værste fald medføre, at enkelte jurymedlemmer møder fastlåst til rådslagningen og ikke er til at rokke, jfr. hjertesukket pag. 139 og typesvarene pag. $322 \mathrm{ff}$.

En person af største betydning er juryformanden eller ordstyreren - i det mod kønnenes lighed så stærkt orienterede Norge er ordet "formann" nærmest udgået af sproget. Flere roser en dygtig ordstyrer; en ordstyrers beskrivelse af sin egen tilrettelæggelse af rådslagningen er et mønster af omhu og omtanke (pag. 134, se også citaterne pag. $311 \mathrm{ff}$. fra det både underholdende og tankevækkende tillæg med typesvar; det bedste udbytte af dette tillæg får man ved stadig at blade tilbage til oversigten over spørgsmålene pag. 80 ff.). Men netop med ordstyrerens betydning in mente er det uheldigt, at ordførervalget sker så hurtigt og så tidligt, pag. $265 \mathrm{ff}$. Hyppigst vælges en midaldrende mand i en passende høj stilling eller endog blot det jurymedlem, der var udtaget som nr. 1, og selvom valget langt oftere har været godt end skidt, er det dog en altfor tilfældig fremgangsmåde. Under en flerdagessag kunne man sagtens vente til den anden dags begyndelse, ordstyreren har jo ingen funktion under de første stadier af hovedforhandlingen. NB: I Danmark vælges ikke længere nævningeformand, da retsformanden leder voteringen.

Mange sider bruges til spørgsmålet som hvad rimelig tvivl eller modsat overbevisning er, og de 117 har den største vanskelighed ved at definere dette (pp. 118 ff., 166 ff., 297 ff.). Bedst er rimelig tvivl defineret af en "reflektert" lægdommer: "Tvil som kan gi fornuftig grunnlag for en alternativ forståelse av bevismaterialet, når denne forståelsen ikke gir grunnlag for fellelse" (pag. 170). Jeg er enig med forf. om, at det næppe kan siges bedre. I øvrigt tager jeg det ikke så tragisk, at det er svært at udtrykke sikkerhed hinsides rimelig tvivl verbalt. En næsten rørende refleksion: "Hvis du om en måned tenker tilbake på din stemmeavgivning og angrer, har du stemt galt" (pag. 300), der er mange tilsvarende umiddelbart menneskelige træk i de spontane svar.

Uanset at forfatteren ender med at bekende sig som tilhænger af en meddomsrettsordning, tilhører en stor del af hans hjerte den klassiske jury, og kap. 5 er viet mulige forbedringer af juryen, ikke ved institutionelle ændringer, men ved bedre rutiner hos både anklager og retsformand, f.eks. ved relevant vejledning til juryen 
om bevisvurderingsproblemer, næsten som en ekstra retsbelæring på et så tidligt stadium, at juryen kan få fornøjelse af den (pag. 162), også ved flere opklarende spørgsmål fra retsformanden (pag. 157). Hvis ikke juryen afskaffes eller radikalt ændres - og med 1981 og 1993 i tankerne kan det da ikke udelukkes, at hensynet til traditionerne fra Sverdrup og 1890 sejrer end en gang - bør dette kapitel nærlæses af nævningesagernes routiniers.

I kapitel 6 om det brændende politiske spørgsmål om lægdommerne og folkestyret får vi atter Sverdrups affærdigende omtale af embedsdommerens esprit de condamnation (pag. 181), der skal neutraliseres af "Mænd, valgte lige ud af Folkets Midte", men også gennemgang af de skiftende udvælgelsesprincipper for lægdommerne, herunder det uhistoriske krav om dom ved ligemænd (pag. 183). En konsekvent gennemførelse af dette krav ville medføre, at lægdommerne ikke skulle være et tværsnit af hele befolkningen, men særskilt udvælges af de samme grupper, hvorfra flertallet af de anklagede kommer, og det er utænkeligt. Det seneste forsøg på at indføre et næsten rent tilfældighedsprincip slog fejl, efter min opfattelse heldigvis (pag. 186 ff., forfatterens udførlige gengivelse af Frostatings negative høringssvar viser, hvor hans egne sympatier ligger).

Et godt argument for at ændre systemet er, at der ikke i dag er reel forskel på, hvordan fag- og lægdommere bedømmer beviserne, jfr. dissensmønstrene i ankesagerne, hvor fag- og lægdommere samvirker (pag. 204 ff.), hvorfor der ikke længere er behov for at isolere lægdommerne. Det andet argument, faren for fagdommerdominans, er ikke helt dødt (pag. 209 ff.), men heroverfor står risikoen for helt ukontrolleret påvirkning jurymedlemmerne imellem eller fra en manipulerende ordstyrer. Det måske stærkeste argument for juryen, traditionen - hvorfor ændre noget, der har bestået i over hundred år og stort set virker godt? - kan lige så godt anføres til fordel for meddomsretterne, som har bestået lige så længe og anvendes i langt flere sager (pag. 240).

En saggruppe angriber forfatteren til sidst, voldtægtssagerne (pag. 244 f.), hvor juryen ofte frifinder efter fældende dom i tingretten. Når man betænker, hvor få voldtægtsanmeldelser der fører til tiltalerejsning, kan der ikke bortses fra, at jurysystemet her medfører risiko for urigtige frifindelser. Med forfatterens ord, for ti skyldige, som går fri, er der ti kvinder, som får livet ødelagt (hvis juryen består, foreslår jeg, at man som i Danmark i 1981 reducerer maksimumsstraffen for voldtægt til fængsel i 6 år i sager uden særdeles skærpende hensyn, hvorved det store flertal ville være fjernede fra juryen; sådan blev man kvit de urimelige frifindelser i sager om uagtsomt drab i færdslen).

Længe holder forfatteren kortene ind til brystet, men til sidst bekender han kulør og foreslår juryen erstattet med en stor meddomsret med fællesvotering, hvorved man særlig vinder, at også disse domme får en fuld begrundelse. Alternativet 
til en ophævelse vil være den danske ordning med en større gruppe lægdommer i "jurysagerne" - man kan såmænd godt bevare navnet "jury" for disse kollegier. Forfatteren vælger ikke her, men jeg tror, at reformtilhængerne ville handle klogt i at foretrække mellemløsningen, som nok lettere vil kunne opnå et flertal i Stortinget.

Forordet og bagsiden nævner den i 1890 afskaffede inkvisitionsordning i samme åndedræt som "danskdominans" og "dansketiden", men ret beset indførtes inkvisitionsprocessen, der var en stor forbedring af tidligere tiders svage næsten private straffeproces, først i 1796, kun 18 år før rigernes adskillelse. Netop på straffeprocessens område gik påvirkningen henimod slutningen af det 19. århundrede den modsatte vej, da den norske reformlov af 1890 fik stor betydning for den danske retsplejereform af 1919 og indførelse af domsmandsordningen i 1937. Hvis Danmark kan betale denne taknemmelighedsgæld tilbage ved at give Norge en inspirationsmodel til en forbedret juryordning, vil det glæde anmelderen af denne meget anbefalelsesværdige bog.

\section{Peter Garde}

Fhv. dommer ved retten i Hillerød. 